\title{
PENGARUH BRAND EXPERIENCE TERHADAP BRAND \\ SATISFACTION, BRAND TRUST DAN BRAND LOYALTY \\ (Studi Pada Konsumen Make-Up Brand Impor di Surabaya)
}

\author{
Agata Rahmi Pertiwi ${ }^{1 *}$, Achmad Helmy Djawahir ${ }^{1}$, Andarwati ${ }^{1}$ \\ ${ }^{1}$ Program Magister Fakultas Ekonomi dan Bisnis, Universitas Brawijaya \\ *agatarahmi92@gmail.com
}

\begin{abstract}
The purposes of this study is to describe and analyze the direct and indirect effect of brand experience on brand satisfaction, brand trust, and brand loyalty of consumers make-up brand cosmetics imports in Surabaya. This study uses questionnaires as the research instrument with 100 respondents as the sample. Sampling technique is convenience sampling. This study uses Partial Least Square (PLS)s to analyzed the data. The results shows that there is a significant direct effect on the brand experience on brand satisfaction, brand trust, and brand loyalty. The results also shows that there are significant indirect influence between brand experience on brand loyalty through brand trust and brand experience on brand trust through brand satisfaction. The other result shows that there is no significant relationship between brand satisfaction on brand loyalty and brand experience on brand loyalty through brand satisfaction.
\end{abstract}

Keywords: Brand Experience, Brand Satisfaction, Brand Trust, Brand Loyalty

\section{PENDAHULUAN}

Pertumbuhan industri kosmetik di Indonesia tergolong solid dimana peningkatan penjualan kosmetik pada tahun 2012 mengalami peningkatan sebesar 14\% dari Rp 8,5 triliun menjadi 9,76 triliun. Banyak faktor yang mempengaruhi pertumbuhan industri kosmetik di Indonesia, salah satunya adalah adanya peningkatan permintaan dari konsumen tingkat menengah akan produk-produk kosmetik yang berkualitas. Selain itu, banyaknya jumlah brand kosmetik impor yang beredar di pasar Indonesia juga memberikan sumbangan terhadap pertumbuhan industri kosmetik. Menurut data Perkosmi, tahun 2014 jumlah penjualan kosmetik impor mencapai 2,44 triliun dimana jumlah ini mengalami kenaikan 30\% dibanding tahun 2011. Peningkatan tersebut didukung oleh kenaikan volume penjualan serta penurunan tarif bea masuk yang muncul akibat adanya perdagangan bebas.

Salah satu faktor yang membuat kosmetik brand impor mampu dengan mudah diterima oleh konsumen Indonesia dikarenakan adanya beberapa karakteristik konsumen Indonesia dalam mengkonsumsi produk. Artikel yang ditulis oleh Handi Irawan dalam marketing.co.id (2012) mengungkapkan bahwa konsumen Indonesia memiliki keunikan dalam hal attitude, perilaku maupun proses pengambilan keputusan dalam mengevaluasi dan membeli produk. Beberapa faktor eksternal yang sangat mempengaruhi perilaku konsumen Indonesia adalah tingkat pendidikan, group reference, dan tingkat socializing yang kuat.

Kosmetik brand impor terkenal seperti L'oreal, Bobbi Brown, Estee Lauder, SKII, The Body Shop, dan brand besar lainnya mengandalkan brand sebagai kekuatan utama untuk bersaing dalam pasar. Brand 
dapat mengidentifikasikan siapa yang membuat produk dan membuat konsumen, baik individual atau organisasi, berhak meminta pertanggungjawaban kinerja produk kepada produsen atau penyalur produk tersebut. Brand yang kuat mampu menciptakan brand loyalty jangka panjang sehingga konsumen mampu melihat brand sebagai produk atau jasa yang baik (Kotler dan Keller, 2012:241).

Loyalty dapat menjadi salah satu keunggulan bersaing bagi produsen brand kosmetik impor. Lovelock dan Wirtz (2011) mengemukakan bahwa loyalty merupakan istilah lama yang digunakan untuk menggambarkan tentang kesetiaan yang mendalam terhadap sebuah negara, kesetiaan terhadap kondisi atau sebab tertentu atau kepada pihak tertentu. Salah satu strategi yang saat ini menarik perhatian banyak produsen kosmetik dan akademisi adalah penggunaan pengalaman atau experience sebagai strategi yang mampu membangun brand loyalty yang efektif. Artikel yang ditulis oleh anonim dalam In-Cosmetics (2016) mengungkapkan kesadaran produsen kosmetik saat ini dalam melihat pengalaman sebagai salah satu cara untuk membangun ikatan yang kuat antara produk mereka dengan konsumen.

Brand experience tidak hanya mampu mempengaruhi brand loyalty secara langsung tetapi juga mampu memberikan pengaruh terhadap brand satisfaction. Penerapan brand experience yang berujung pada brand satisfaction terhadap brand pada akhirnya menghantarkan konsumen pada hubungan yang lebih dari sekedar puas. Brand satisfaction yang sesuai atau bahkan melebihi ekspektasi akan membawa konsumen kepada hubungan afektif yang lebih penting dari hubungan pribadi antara brand dengan konsumen, yakni brand trust. Brand trust terbukti sebagai salah satu inti dalam membangun hubungan kuat antara brand dengan konsumen dan secara positif mempengaruhi brand loyalty.

Produsen kosmetik brand impor menyadari bahwa perempuan merupakan konsumen utama produk mereka. Perempuan memiliki pola tersendiri dalam konsumsinya yang sebagian besar dipengaruhi oleh tingkatan umur mereka. Berbagai macam produk kosmetik dihasilkan oleh produsen dan salah satu produk kosmetik yang paling sering dikonsumsi oleh perempuan adalah make-up. Survei yang dilakukan oleh Statista menunjukkan persentase market share kosmetik di dunia berdasarkan kategori produk dimana make-up menduduki posisi ke tiga sebagai kategori produk kosmetik yang memiliki market share tertinggi.

Make-up sebagai salah satu jenis kosmetik yang paling sering di konsumsi oleh perempuan menjadikan jenis kosmetik ini sangat mudah di temui. Salah satu kota besar di Indonesia yang terkenal dengan pusat perbelanjaannya adalah Surabaya. Sebanyak 33 pusat perbelanjaan besar berada di Surabaya dan banyak dari pusat perbelanjaan tersebut yang menyediakan make-up impor dari berbagai brand ternama.

\section{Marketing dan Experiential Marketing}

Pemasaran (marketing) adalah tentang mengidentifikasi dan memenui kebutuhan manusia dan sosial. Definisi terpendek dari pemasaran adalah pertemuan antar kebutuhan yang menguntungkan (Kotler dan Keller, 2012:5).

Bernd H. Schmitt (1999:22) mendefinisikan pengalaman sebagai peristiwa khusus yang terjadi pada orang sebagai tanggapan atas beberapa jenis rangsangan. Pemasaran experiential marketing memiliki empat karakteristik utama, yakni:

a. Customer experience

Experiential marketing memiliki fokus yang berbeda dengan pemasaran tradisional yang terbatas pada keuntungan dan keunggulan fungsional saja, experiential marketing lebih berfokus pada pengalaman konsumen.

b. Consumption as holistic experience Dalam experiential marketing, seorang marketer harus mampu mengukur situasi konsumsi dan menggambarkan beberapa lingkungan kategori serta persaingan 
berdasarkan jumlah perubahan pola pikir mengenai peluang pasar.

c. Customer are rational and emotional animals

Penting bagi seorang experiential marketer untuk menganggap konsumen sebagai seekor binatang yang dilengkapi dengan kemampuan mental dan fisik untuk memahami sensasi, pemikiran, dan perasaan yang terjadi di lingkungan sekitar mereka untuk menyelesaikan masalah yang ada.

d. Method are electic.

Experiential marketing tidak terikat hanya pada satu metode atau alat saja. Beberapa metode atau alat yang digunakan dapat berupa metode atau alat analitis atau kuantitatif atau justru lebih mengarah pada metode intuitif dan kualitatif. Metode atau alat yang digunakan seorang experiential marketer bergantung pada objek yang saat ini mereka hadapi.

\section{Merek (Brand)}

Merek merupakan salah satu aset tidak berwujud yang bernilai bagi perusahaan dan merupakan tugas berat seorang pemasar untuk mengelola nilai sebuah brand dengan benar. The American Marketing Association dalam Kotler dan Keller (2012:241) mendefinisikan brand sebagai nama, tanda, simbol, desain, atau gabungan dari beberapa hal tersebut yang bertujuan untuk mengidentifikasikan barang atau jasa yang ditawarkan satu atau lebih penjual dan membedakan mereka dari pesaing.

\section{Brand Experience}

Brand experience dapat diartikan sebagai sebuah sensasi, perasaan, kognisi, dan perilaku yang merupakan hasil rangsangan brand terkait dimana brand experience dikaitkan dengan desain brand, kemasan, komunikasi, dan lingkungan (Brakus et al., 2009). Brand experience melibatkan empat dimensi yakni sensory, affective, behavioral, dan intellectual (Brakus et al.,2009).

\section{Dimensi dari Brand Experience}

Penelitian terdahulu yang dilakukan oleh Brakus et al. (2009) mengemukakan empat dimensi dari brand experience, yaitu:

a. Sensory

Sensory experience berfokus pada bagaimana brand atau brand mampu membuat konsumen kagum dan merasa tertarik.

b. Affective

Afektif merupakan salah satu dari tiga komponen yang mampu menjelaskan sikap seseorang (konsumen potensial) terhadap suatu objek atau fenomena (Pallister dan Isaacs, 2003).

c. Behavioral

Dimensi behavioral dalam brand experience berkaitan dengan perilaku motorik dan pengalaman perilaku yang dapat diciptakan brand melalui desain produk dan identitas, kemasan, komunikasi, serta lingkungan.

d. Intellectual

Intellectual experience sebagian besar mengarah pada kemampuan untuk berfikir dan menyelesaikan masalah secara kognitif dengan menggunakan konsep 'intellectual' yang dibedakan menjadi dua faktor utama yaitu faktor berfikir dan ingatan serta faktor yang melibatkan kesadaran, produk, dan evaluasi.

\section{Brand Satisfaction dan Brand Trust Brand Satisfaction}

Dalam cakupan brand experience, brand satisfaction dapat diartikan sebagai hasil dari penilaian subjektif seseorang ketika alternatif brand yang dipilih mampu memenuhi atau melebihi ekspektasi (Engel et al., 1990). Kualitas dari sebuah hubungan dengan brand dapat dilihat dari sejauh mana konsumen melihat brand sebagai rekan yang mampu memberikan kepuasan dalam hubungan yang sedang berjalan (Algesheimer et al, 2005).

\section{Brand Trust}

Kepercayaan terhadap brand dapat diartikan sebagai perasaan nyaman yang mampu dirasakan konsumen terhadap brand 
berdasarkan keyakinan dan ekspektasi bahwa brand mampu memberikan hasil positif baginya (Lau dan Lee, 1999). DelgadoBallester et al. (2003) mengemukakan bahwa brand trust tidak hanya datang dari keyakinan personal, tetapi brand juga harus memiliki reputasi yang dapat diandalkan, jujur, kredibel, konsisten dan bertanggung jawab terhadap konsumen.

\section{Brand Loyalty}

Yim et al., dalam Alrubaiee dan AlNazer (2010) mendefinisikan loyalitas sebagai komitmen mendalam untuk membeli kembali atau berlangganan kembali produk atau jasa tertentu di masa yang akan datang meskipun terdapat beberapa pengaruh situasional dan marketing effort yang memungkinkan pelanggan untuk mengganti produk atau jasa yang dipilihnya. Loyalitas jika ditinjau dari brand loyalty didefinisikan sebagai perilaku, maka dapat diartikan bahwa brand loyalty diartikan sebagai pembelian berulang suatu brand secara konsisten oleh pelanggan. Sedangkan loyalitas yang ditinjau dari perspektif sikap meninjau bagaimana perasaan atau sikap konsumen terhadap brand tertentu dibandingkan dengan brand lainnya (Dick dan Basu; Tjiptono,2001: 110 dalam Gamma, 2006:41)

\section{Hubungan antara Brand Experience dengan Brand Satisfaction}

Bolton (1998) mengemukakan bahwa pengalaman yang memuaskan dapat memperpanjang hubungan antara konsumen dengan perusahaan. Ia menambahkan bahwa kepuasan merupakan kunci inti untuk mengukur apakah konsumen mau tetap loyal atau justru menghentikan hubungan mereka dengan brand yang ditawarkan perusahaan. Kekuatan dari sebuah hubungan jika dilihat dari jangka waktu hubungan tersebut dan tingkat kepuasan yang dimiliki konsumen bergantung pada seberapa lama pengalaman yang dirasakan konsumen dengan brand dimana konsumen yang memiliki pengalaman dengan jangka waktu lebih panjang memiliki kemungkinan besar untuk merasa lebih puas dibandingkan mereka yang memiliki pengalaman dengan jangka waktu lebih pendek. Dapat disimpulkan bahwa ketika konsumen merasa bahwa ia memperoleh pengalaman yang positif dari brand maka ia akan memperoleh kepuasan positif juga.

\section{Hubungan antara Brand Experience dengan Brand Trust}

Beberapa karakteristik dari brand seperti reliability, intention, credibility, dan honesty secara positif terkait dengan kepercayaan konsumen terhadap brand yang ditawarkan perusahaan (Luk dan Yip, 2008). Koufaris dan Hampton-Sosa (2002) berpendapat bahwa pengalaman yang mampu menimbulkan kepercayaan konsumen dapat diciptakan oleh penjual atau perusahaan. Namun, untuk menciptakan pengalaman yang mampu menimbulkan kepercayaan tersebut, penjual atau perusahaan harus memiliki beberapa karakteristik seperti menjadi perusahaan yang memang ahli dalam bidangnya dan keinginan untuk selalu mendampingi konsumen pada kondisi apapun.

\section{Hubungan Brand Satisfaction dengan Brand Trust}

Kepuasan terhadap brand dapat menjadi salah satu alat ukur untuk mengetahui apakah ada hubungan yang baik dalam kegiatan pertukaran yang terjadi. Konsumen akan merasa puas dengan kinerja brand yang ditawarkan jika kinerja brand tersebut sesuai, atau bahkan melebihi ekspektasi mereka. Brand satisfaction yang berhasil dirasakan konsumen akan membawa mereka kepada hubungan afektif yang lebih penting dari hubungan pribadi antara brand dengan konsumen, yakni kepercayaan. Konsumen yang beranggapan bahwa brand mampu memenuhi janji yang ditawarkan serta mengutamakan kepentingan mereka dibandingkan kepentingan perusahaan ketika terjadi masalah menunjukkan adanya kepercayaan terhadap brand (DelgadoBallester, 2004). 
Hubungan antara Brand Experience dengan Brand Loyalty

Brand

experience

dapat

menghantarkan pada brand loyalty, penyerahan secara aktif dari brand, dan meningkatkan keuntungan dari brand (Morrison dan Crane, 2007). Brand experience mampu mendorong timbulnya loyalitas dengan menciptakan hubungan emosional melalui suatu konteks yang mengikat, memaksa, dan konsisten. Konteks yang dimaksud di sini adalah lingkungan dimana layanan diberikan, yakni kondisi fisik dan karakteristik situasi ketika konsumen mengkonsumsi layanan atau brand serta interaksi mereka dalam situasi tersebut. Singkatnya, brand experience mampu menyajikan situasi yang membuat konsumen memutuskan apakah mereka akan loyal terhadap brand atau layanan yang diberikan perusahaan.

\section{Hubungan antara Brand Satisfaction dengan Brand Loyalty}

Brand loyalty dapat diidentifikasikan sebagai aspek penting yang dipengaruhi oleh kepuasan konsumen terhadap brand tersebut (Chandrashekaran et al., 2007). Konsumen yang puas merupakan konsumen yang memiliki potensi untuk loyal terhadap brand (Magin et al., 2003). Kepuasan akan mempengaruhi konsumen dalam hal behavioral, attitudinal, dan lain sebagainya (Gounaris dan Stathakopoulos,2004). Selain itu, kepuasan memiliki hubungan positif ataupun negatif dengan perilaku, keyakinan, dan emosi konsumen. Dapat dikatakan bahwa perilaku, keyakinan, dan emosi merupakan komponen utama yang membentuk loyalitas. Singkatnya, kepuasan yang positif akan menghasilkan ikatan lebih erat dengan loyalitas (Jones dan Smith, 2000)

\section{Hubungan antara Brand Trust dengan Brand Loyalty}

Persepsi konsumen terhadap brand tertentu akan mengarah pada trust atau distrust dimana hal ini akan mempengaruhi evaluasi mereka mengenai apakah mereka akan melanjutkan hubungan dengan brand atau tidak (Lau dan Lee, 1999). Perilaku konsumen yang positif terhadap brand akan menghantarkan mereka pada loyalitas. Sebaliknya, jika perusahaan tidak mampu membuat konsumen menunjukkan perilaku positif terhadap brand maka perusahaan akan semakin jauh dari harapan memperoleh kepercayaan mereka dan loyalitas mereka.

\section{METODE}

\section{Kerangka Konsep Model Penelitian}

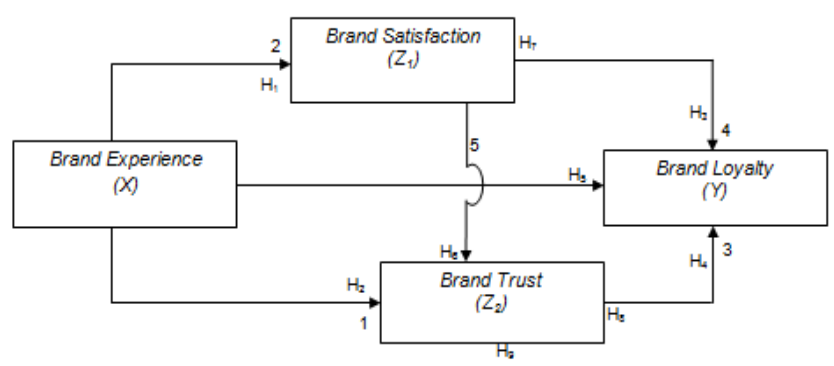

Gambar 1: Kerangka Konsep Model Penelitian

Sumber kerangka konsep model penelitian:

1. Chaudhuri, Arjun dan Holbrook, B.M (2001)

2. J. Josko Brakus, Bernd H. Schmitt, dan Lia Zarantonello (2009)

3. Azize Sahin, Cemal Zehir, dan Hakan Kitapc1 (2011)

4. Young Gin Choi, Chihyung Ok, dan Seunghyup Seon Hyun (2011)

5. Asadollahi et al. (2012)

\section{Hipotesis}

Terkait dengan experiental marketing, beberapa ahli telah menemukan bahwa kepuasan terkait dengan brand experience dan customer experience (Brakus et al.,2009; Bennet et al.,2005; Ha dan Perks,2005).

$\mathrm{H}_{1} \quad$ : brand experience berpengaruh signifikan terhadap brand satisfaction.

Delgado-Ballester dan Munuera-Aleman (2005) mengemukakan bahwa kepercayaan pada sebuah brand dapat dilihat dari pemahaman mengenai pengalaman sebelumnya, sama halnya dengan brand experience. 
$\mathrm{H}_{2} \quad$ : brand experience berpengaruh signifikan terhadap brand trust.

Bennett (2001) mengemukakan bahwa kepuasan merupakan awal dari terbentuknya brand loyalty dimana peningkatan kepuasan akan menghantarkan pada peningkatan brand loyalty.

$\mathrm{H}_{3}$ : brand satisfaction berpengaruh signifikan terhadap brand loyalty.

Bart et al. (2005) mengemukakan bahwa brand merupakan tanda kepercayaan bagi seluruh aktivitas tidak berwujud yang terkait dengan pembentukan kepercayaan, dimana aktivitas ini tidak melibatkan sentuhan fisik antar manusia, dan dapat menjadi simbol dari kualitas dan jaminan dalam membangun kepercayaan.

$\mathrm{H}_{4} \quad$ : brand trust berpengaruh signifikan terhadap brand loyalty.

Ponsonby -McCabe dan Boyle (2006) menemukan bahwa ada dua macam kondisi yang mempengaruhi hubungan antara brand experience dan loyalty. Pertama, konsumen akan memiliki keinginan untuk melakukan pembelian ulang terhadap brand yang sama berulang ulang kali karena adanya pengalaman baik dengan brand di masa lalu. Kedua, konsumen meyakini bahwa brand experience mampu menghantarkan pada keuntungan bernilai yang sesuai dengan harga yang harus mereka bayar.

$\mathrm{H}_{5} \quad$ : brand experience berpengaruh signifikan terhadap brand loyalty.

Asadollahi et al. (2012) dalam penelitiannya menjadikan hubungan antara brand satisfaction dan brand trust salah satu hipotesis. Kepuasan merupakan hasil pertama dari hubungan timbal balik antara konsumen dengan brand yang mereka konsumsi, dimana konsumen tentu berharap memperoleh kepuasan sesuai dengan harga yang mereka bayar. Tahap selanjutnya dari hubungan ini adalah kepercayaan yang timbul dari hasil kepuasan yang melebihi ekspektasi.

$\mathrm{H}_{6}$ : brand satisfaction berpengaruh signifikan terhadap brand trust.

Ketika sebuah brand berhasil memberikan pengalaman yang sesuai atau bahkan melebihi harapan konsumen maka akan lebih mudah bagi brand tersebut untuk mempertahankan konsumen. Telah dijelaskan sebelumnya bahwa kepuasan merupakan awal terbentuknya brand loyalty. Ketika brand experience yang dilakukan telah mampu memberikan kepuasan maka akan lebih mudah bagi produsen untuk memperoleh brand loyalty.

$\mathrm{H}_{7}$ : brand experience berpengaruh signifikan terhadap brand loyalty melalui brand satisfaction.

Penelitian terdahulu yang dilakukan oleh Delgado-Ballester dan Munuera-Aleman (2005), Yoon (2002), dan beberapa peneliti lainnya telah mengungkapkan bahwa brand experience mampu mempengaruhi kepercayaan konsumen. Pengalaman positif yang dirasakan konsumen dapat meningkatkan atau bahkan menurunkan brand trust mereka.

$\mathrm{H}_{8}$ : brand experience berpengaruh signifikan terhadap brand loyalty melalui brand trust.

Beberapa penelitian terdahulu seperti yang dilakukan oleh Brakus et al. (2009), Sahin, Zahir, dan Kintapci (2011) serta Walter et al., (2013) juga membuktikan bahwa ada hubungan yang positif signifikan antara brand experience dan brand satisfaction. Brand experience merupakan alat untuk membentuk kepuasan dimana kepuasan sendiri merupakan hasil awal dari hubungan yang tercipta antara konsumen dan brand melalu pengalaman yang telah dirasakan. Kepuasan tersebut pada akhirnya berkembang menjadi kepercayaan karena kepercayaan timbul melalui hubungan timbal balik yang berkelanjutan.

$\mathrm{H}_{9}$ : brand experience berpengaruh signifikan terhadap brand trust melalui brand satisfaction.

\section{Rancangan Penelitian}

Metode penelitian yang digunakan dalam penelitian ini adalah metode penelitian kuantitatif (positivis). Jenis penelitian yang digunakan adalah jenis penelitian eksplanatori. 


\section{Lokasi Penelitian}

Penelitian ini dilakukan di salah satu kota besar di Jawa Timur, yakni Surabaya, tepatnya pada lima pusat perbelanjaan atau mall besar yang berada di tiap wilayah Kota Surabaya sebagai berikut :

Tabel 1. Lokasi Penelitian

\begin{tabular}{|c|c|}
\hline $\begin{array}{c}\text { Wilayah } \\
\text { Surabaya }\end{array}$ & $\begin{array}{c}\text { Nama Pusat } \\
\text { Perbelanjaan }\end{array}$ \\
\hline Surabaya Pusat & Tuniungan Plaza \\
\hline Surabaya Barat & $\begin{array}{c}\text { Supermall Pakuwon } \\
\text { Indah (SPI) }\end{array}$ \\
\hline Surabaya Utara & - \\
\hline Surabaya Timur & Grand City, Galaxy Mall \\
\hline Surabaya Selatan & Ciputra World \\
\hline
\end{tabular}

\section{Populasi Penelitian}

Populasi dalam penelitian ini adalah seluruh pelanggan yang melakukan pembelian kosmetik jenis make-up brand impor di Surabaya, dengan kriteria sebagai berikut :

a. Pelanggan pernah melakukan pembelian make-up di gerai kosmetik impor pada paling sedikit satu dari lima pusat perbelanjaan di Kota Surabaya, yakni Tunjungan Plaza, Grand City, Galaxy Mall, Supermall Pakuwon Indah, dan Ciputra World.

b. Pelanggan pernah melakukan pembelian make-up brand impor lebih dari satu kali.

c. Perempuan dengan umur kurang dari 50 tahun.

\section{Sampel Penelitian}

Teknik sampling yang digunakan dalam penelitian ini adalah non-probability sampling. Jenis teknik non-probability sampling yang digunakan adalah convenience sampling. Penentuan jumlah responden penelitian didasarkan pada rule of thumb yang dinyatakan oleh Barclay, Higgins dan Thompson pada Hair et al. (2014:20) dimana ukuran sampel harus sama atu lebih besar dari:

1. Jumlah indikator yang digunakan untuk mengukur variabel dikali dengan 10 , atau

2. Jumlah jalur struktural terbanyak yang mengarah pada setiap variabel pada model struktural dikali sepuluh.
Berdasarkan rule of thumb tersebut maka pada penelitian ini ditentukan jumlah sampel sebanyak 100 responden.

\section{Teknik Pengumpulan dan Pengukuran Data.}

Teknik pengumpulan data dalam penelitian dilakukan menggunakan beberapa cara yaitu menggunakan angket atau kuesioner dan wawancara. Skala pengukuran yang digunakan dalam penelitian ini adalah skala Likert dengan lima tingkatan.

\section{Uji Instrumen Penelitian (Pilot Testing)}

Pilot testing dilakukan dengan cara menyebarkan 30 kuesioner kepada responden. Hasil Pilot testing kemudian diuji untuk mengetahui validitas dan reliabilitas kuesioner sebagai instrumen penelitian. Uji validitas dan reliabilitas dalam penelitian ini dilakukan menggunakan bantuan dari program statistik SPSS 18.0. Item kuesioner dikatakan valid jika nilai korelasi tiap butir pertanyaan berada diatas cut off 0,3 . Item penelitian dikatakan reliable jika nilai koefisien Alpha Cronbach $\geq 0,6$.

\section{Teknik Analisis Data}

Analisis statistik dalam penelitian ini akan dibantu program linearitas SPSS versi 18.0 dan PLS versi 3.0.

\section{Analisis Deskriptif}

Analisis statistik deskriptif digunakan untuk mendeskripsikan variabel penelitian dan memberikan gambaran mengenai karakteristik responden serta menyusun distribusi frekuensi dengan menggunakan data berupa angka yang telah diperoleh dari kuesioner.

\section{Analisis Inferensial}

Dalam penelitian ini, analisis inferensial dilakukan dengan menggunakan pendekatan Partial Least Square (PLS).

\section{Pengukuran Model (Outer Model)}

Outer model dapat dikatakan sebagai model pengukuran untuk menguji reliabilitas dan validitas suatu instrumen,. Parameter 
dalam model pengukuran PLS akan disajikan dalam tabel berikut:

Tabel 2. Parameter Uji Validitas dan Reliabilitas dalam Model Pengukuran PLS

\begin{tabular}{|c|c|c|}
\hline Pengujian & Parameter & Rule of Thumb \\
\hline \multirow{3}{*}{$\begin{array}{c}\text { Uji validitas } \\
\text { konyergen }\end{array}$} & Outer loading & Lebih dari 0.6 \\
\hline & $\begin{array}{c}\text { Average variance } \\
\text { extracted }\end{array}$ & Lebih dari 0.5 \\
\hline & Communality & Lebih dari 0.5 \\
\hline $\begin{array}{l}\text { Uji validitas } \\
\text { diskriminan }\end{array}$ & Cross loading & $\begin{array}{c}\text { Diharapkan setiap } \\
\text { blok indikator } \\
\text { memiliki loading } \\
\text { lebih tinggi untuk } \\
\text { setiap variabel laten } \\
\text { yang diukur } \\
\text { dibandingkan } \\
\text { dengan indikator } \\
\text { untuk variabel laten } \\
\text { lainnya }\end{array}$ \\
\hline \multirow{2}{*}{$\begin{array}{c}\text { Uji } \\
\text { reliabilitas }\end{array}$} & Croncbach Alpha & Lebih dari 0.6 \\
\hline & Composite reliability & Lebih dari 0.6 \\
\hline
\end{tabular}

\section{Model Struktural (Inner Model)}

Parameter pengukuran inner model pada PLS dapat dijelaskan sebagai berikut (Hair et al., 2014:170):

\section{1. $R$-squared $\left(\mathrm{R}^{2}\right)$}

Semakin tinggi nilai $\mathrm{R}^{2}$ maka semakin baik model prediksi dari model penelitian yang diajukan.

2. Koefisien Path.

Kriteria untuk menolak dan menerima hubungan yang diajukan dapat dilihat dari perbandingan antar nilai t-hitung dan ttabel. Jika nilai t-hitung > t-tabel, yaitu 1,96 maka Ha diterima.

\section{Metode Sobel}

Metode sobel dalam penelitian ini digunakan untuk menguji hipotesis mediasi dengan cara menguji kekuatan pengaruh tidak langsung variabel independen (X) ke variabel dependen (Y) melalui variabel intervening $(\mathrm{Z})$. Metode pemeriksaan variabel mediasi mengacu pada teori yang dikemukakan oleh barin dan Kenny (1986).

\section{HASIL DAN PEMBAHASAN Pengujian Instrumen Penelitian (Pilot Testing) \\ Uji Validitas}

Hasil uji validitas 30 responden yang menjadi bagian pilot test menunjukkan bahwa seluruh item yang digunakan dalam penelitian ini valid. Validitas item kuesioner dapat dilihat dari nilai korelasi pearson yang lebih besar dari cut off 0.3 .

\section{Uji Reliabilitas}

Hasil uji reliabilitas pada 30 responden yang diperoleh dari pilot test menunjukkan bahwa semua item dalam instrumen penelitian telah reliabel karena nilai koefisien cronbach alpha berada diatas 0.6 .

\section{Analisis Partial Least Square (PLS)}

\section{Evaluasi Model Pengukuran (Outer Model)}

a. Validitas Konvergen (Convergent Validity)

Hasil uji validitas konvergen menunjukkan bahwa seluruh item yang mengukur variabel penelitian memiliki nilai loading factor diatas 0.6 dan menunjukkan bahwa semua item instrumen dikatakan valid dalam mengukur variabel penelitian. Beberapa item yakni item brand experience (BE) 2.1, brand experience (BE) 2.3, brand experience (BE) 3.3, dan brand experience (BE) 4.3 harus dihapus karena memiliki nilai loading factor di bawah 0.6 yang menandakan bahwa item pertanyaan pada kuesioner tidak valid dalam mengukur indikator. Nilai AVE disajikan pada tabel berikut:

Tabel 3. Nilai AVE

\begin{tabular}{|c|c|c|c|c|}
\hline Variabel & AVE & Communality & $\begin{array}{c}\text { Cut } \\
\text { Off }\end{array}$ & Keterangan \\
\hline $\begin{array}{c}\text { Brand } \\
\text { experience }\end{array}$ & 0.519 & 0.519 & 0.5 & Valid \\
\hline $\begin{array}{c}\text { Brand } \\
\text { satisfaction }\end{array}$ & 0.578 & 0.578 & 0.5 & Valid \\
\hline Brand trust & 0.511 & 0.593 & 0.5 & Valid \\
\hline Brand lovalty & 0.593 & 0.511 & 0.5 & Valid \\
\hline
\end{tabular}

Sumber : data diolah

Hasil menunjukkan bahwa nilai AVE berada diatas 0.5 sehingga instrumen penelitian yang digunakan dapat dikatakan valid.

b. Validitas Diskriminan (Discriminant Validity)

Nilai masing-masing item variabel terkait lebih besar dibandingkan nilai item dari variabel lain. Hasil tersebut menunjukkan 
bahwa masing-masing item pada variabel terkait terbukti valid dan memiliki keunikan dibandingkan item pada variabel lain.

c. Reliabilitas

Nilai cronbach alpha dan composite reliability dari variabel brand experience, brand satisfaction, brand trust, dan brand loyalty seluruhnya berada diatas nilai cut off 0.6. Dapat disimpulkan jika seluruh variabel dalam penelitian telah reliabel.

\section{Evaluasi Model Struktural (Inner Model)}

a. Path Model

Brand experience mempengaruhi brand satisfaction sebesar 0.606 atau $60.6 \%$, brand experience mempengaruhi brand trust sebesar 0.341 atau $34.1 \%$, brand experience mempengaruhi brand loyalty sebesar 0.287 atau $28.7 \%$, brand satisfaction mempengaruhi brand loyalty secara negatif sebesar -0.184 atau $-18.4 \%$, brand trust mempengaruhi brand loyalty sebesar 0.575 atau $57.5 \%$, dan brand satisfaction mempengaruhi brand trust sebesar 0.400 atau $40 \%$. Gambar path model adalah sebagai berikut:

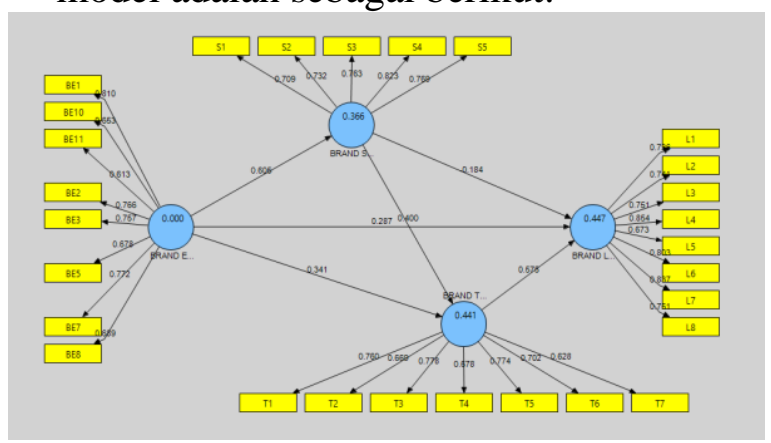

Gambar 2. Path Model

b. Goodness of Fit Model

$\mathrm{Q}^{2}$ penelitian ini disajikan pada tabel berikut:

Tabel 4.Goodness of Fit Model

\begin{tabular}{|c|c|c|c|}
\hline Variabel & $\begin{array}{c}\text { Crophach } \\
\text { Alpha }\end{array}$ & Cut Off & Keterangan \\
\hline Brand experience & 0.756 & 0.6 & Reliabel \\
\hline Brand Satisfaction & 0.663 & 0.6 & Reliabel \\
\hline Brand trust & 0.776 & 0.6 & Reliabel \\
\hline Brand lovalty & 0.672 & 0.6 & Reliabel \\
\hline
\end{tabular}

Nilai 0.804 atau $80.4 \%$ menunjukkan bahwa variabel brand satisfaction, brand trust, dan brand loyalty mampu memberikan kontribusi keragaman kepada brand experience sebesar $80.4 \%$.

\section{Pengujian Hipotesis \\ Pengujian Pengaruh Langsung}

Tabel 5. Hasil Pengujian Hipotesis Langsung

\begin{tabular}{|c|l|c|c|c|c|}
\hline Hipotesis & \multicolumn{1}{|c|}{ Hubungan } & $\begin{array}{c}\text { Path } \\
\text { Coefficients }\end{array}$ & T-Hitung & T-Tabel & Keterangan \\
\hline $\mathrm{H}_{1}$ & $\begin{array}{l}\text { brand experience } \\
\text { brand satisfaction }\end{array}$ & 0.605 & 8.306 & 1.96 & Signifikan \\
\hline $\mathrm{H}_{2}$ & $\begin{array}{l}\text { brand experience } \rightarrow \\
\text { brand trust }\end{array}$ & 0.341 & 4.454 & 1.96 & Signifikan \\
\hline $\mathrm{H}_{3}$ & $\begin{array}{l}\text { brand satisfaction } \rightarrow \\
\text { brand loyalty }\end{array}$ & -0.184 & 1.792 & 1.96 & $\begin{array}{c}\text { Tidak } \\
\text { Signifikan }\end{array}$ \\
\hline $\mathrm{H}_{4}$ & $\begin{array}{l}\text { brand trust } \rightarrow \\
\text { brand loyalty }\end{array}$ & 0.575 & 6.624 & 1.96 & Signifikan \\
\hline $\mathrm{H}_{5}$ & $\begin{array}{l}\text { brand experience } \rightarrow \\
\text { brand loyalty }\end{array}$ & 0.287 & 3.027 & 1.96 & Signifikan \\
\hline $\mathrm{H}_{5}$ & $\begin{array}{l}\text { brand satisfaction } \rightarrow \\
\text { brand trust }\end{array}$ & 0.400 & 6.234 & 1.96 & Signifikan \\
\hline
\end{tabular}

Sumber : data diolah

\section{Pengujian Pengaruh Tidak Langsung}

Tabel 6. Hasil Pengujian Hipotesis Tidak Langsung

\begin{tabular}{|c|c|c|c|c|c|}
\hline Hipotesis & \multicolumn{1}{|c|}{ Hubungan } & p-value & $\begin{array}{c}\text { T- } \\
\text { Hitung }\end{array}$ & T-Tabel & Keterangan \\
\hline $\mathrm{H}_{7}$ & $\begin{array}{l}\text { brand experience } \rightarrow \\
\text { brand satisfaction } \rightarrow\end{array}$ & 0.079 & 1.752 & 1.96 & $\begin{array}{c}\text { Tidak } \\
\text { brand loyalty }\end{array}$ \\
\hline $\mathrm{H}_{8}$ & $\begin{array}{l}\text { brand experience } \\
\text { brand trust } \rightarrow \\
\text { branan } \\
\text { brand loyalty }\end{array}$ & 0.000 & 3.697 & 1.96 & Signifikan \\
\hline $\mathrm{H}_{9}$ & $\begin{array}{l}\text { brand experience } \\
\text { brand satisfaction } \rightarrow \\
\text { brand trust }\end{array}$ & 0.000 & 4.986 & 1.96 & Signifikan \\
\hline
\end{tabular}

Sumber : data diolah

\section{Pemeriksaan Variabel Mediasi Pengujian Intervensi Variabel Mediasi Hipotesis 7}

Diketahui bahwa (a) dan (c) signifikan, sedangkan (b) dan (c') tidak signifikan sehingga dapat disimpulkan bahwa tidak terdapat hubungan mediasi. Gambar pengujian intervensi variabel mediasi hipotesis 7 sebagai berikut:

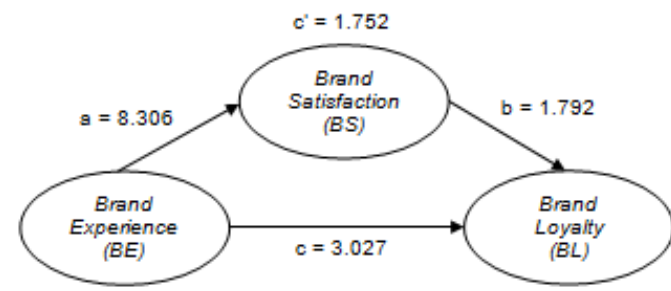

Gambar 3. Pengujian Intervensi Variabel Hipotesis 7 
Pengujian Intervensi Variabel Mediasi Hipotesis 8

Melalui kriteria pengujian intervensi variabel mediasi yang telah dijelaskan sebelumnya diketahui bahwa (a), (b), (c), dan (c') signifikan sehingga dapat disimpulkan bahwa terdapat hubungan mediasi sebagian (partial mediation). Gambar pengujian intervensi variabel mediasi hipotesis 8 sebagai berikut:

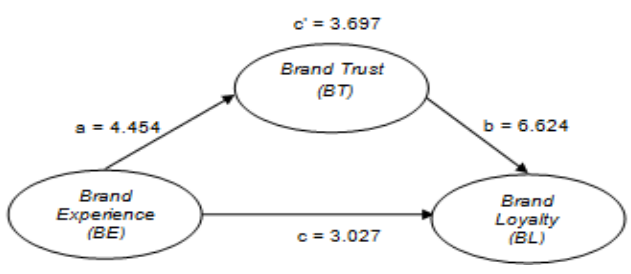

Gambar 4. Pengujian Intervensi Variabel Hipotesis 8

\section{Pengujian Intervensi Variabel Mediasi Hipotesis 9}

Melalui kriteria pengujian intervensi variabel mediasi yang telah dijelaskan sebelumnya diketahui bahwa (a), (b), (c), dan (c') signifikan sehingga dapat disimpulkan bahwa terdapat hubungan mediasi sebagian (partial mediation). Gambar pengujian intervensi variabel mediasi hipotesis 9 sebagai berikut:

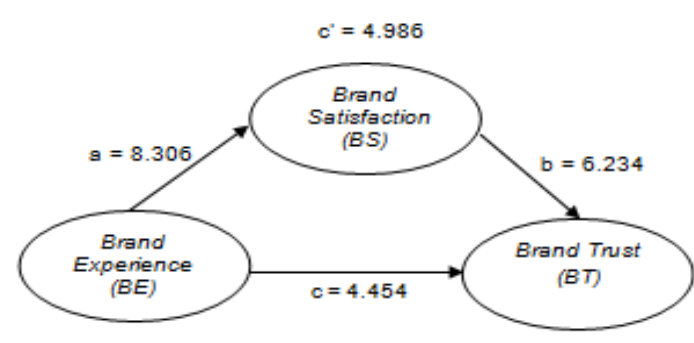

Gambar 5. Pengujian Intervensi Variabel Hipotesis 9

\section{Kesimpulan}

Brand experience dalam penelitian ini terbukti mampu mempengaruhi brand satisfaction, brand trust, dan brand loyalty konsumen make-up brand impor di Surabaya secara langsung. Brand experience juga mempengaruhi brand loyalty melalui mediasi brand trust namun brand experience tidak mempengaruhi brand loyalty melalui mediasi brand satisfaction konsumen makeup brand impor.

\section{DAFTAR PUSTAKA}

Agustin, Clara dan Singh, Jagdip. 2005. Curvilinear Effects of Consumer Loyalty Determinants in Relational Exchanges. Journal of Marketing Research. Vol 13.

Ahniar, Nur Farida dan Pratomo, Harwanto Bimo. 2011. Beda Perilaku Konsumen Kelas Atas dan Menengah, http://viva.co.id/. Agustus 2016.

Algesheimer, Rene., Dholakia, Utpal dan Herrmann, Andreas. 2005. The Social Influence of Brand Community: Evidence from European Car Clubs. Journal of Marketing 69 (7): 19-34.

Alloza, Angel. 2008. Brand Engagement and Brand Experience At BBVA, The Transformation of a 150 Years Old Company. Corporate Reputation Review. Vol.11. no. 4 p.371-381.

Alrubaiee, Laith dan Al-NAzer, Nahla 2010. Investigate the Impact of Relationship Marketing Orientation on Customer Loyalty : The Customer's Perspective. International journal of Marketing Studies. Vol. 2, No.1. Pp. 155-17

Ambler, Tim., Bhattacharya C.B ., Edell, Julie., Keller, Kevin Lane., Lemon, Katherine N., dan Mittal, Vikas. 2002. Relating Brand And Customer Perspectives On Marketing Management. Journal of Service Research Vol. 5(1):13-26.

Amine, Abdelmajid. 1998. Consumers' True Brand Loyalty: The Central Role of Commitment. Journal of Strategic Marketing. Vol 6, p. 305-319.

Anderson, Eugene W. dan Sullivan, Marry W. 1993. The antecedents and consequences of customer satisfaction 
for firms. Marketing Science 12 (2): 125-143.

Antara News. 2010. 15 Perusahaan Kosmetik Perancis akan Jajaki Investasi di Indonesia, www.antaranews.com. Maret 2016.

Asadollahi, Amin., Jani Mohammad., Mojaveri, Parisa Pourmohammadi., dan Allahabadi, Farshad Bastani. 2012. Investigating the Effect of Brand Satisfaction, Brand Trust and Brand Attachment on Purchase Behavior of Customers. Research Journal of Applied Sciences, Engineering and Technology. 4(17):3182-3187.

Ashley, Christy dan Leonard, Hillary. A. 2009. Betrayed by The Buzz? Covert Content and Consumer-Brand Relationships. Journal of Public Policy and Marketing. Vol.28, no 2 p.212220.

Badan Pusat Statistik. 2015. Produk Domestik Bruto Atas Dasar Harga Berlaku Menurut Lapangan Usaha (Miliar Rupiah). http://bps.go.id/. Desember 2015.

Badische, Anilin dan Sodafabrik. 2012. Review of cosmetics regulations in Asia. https://www.basf.com/en.html, Juli 2015.

Bae, Young Han. 2012. Three Essays in the Customer Satisfaction-Customer Loyalty Association. Disertasi Universitas Iowa.

Bagozzi, Richard P dan Heatherton, Todd F. 1994. A General Approach to Representing Multifaceted Personality Constructs: Application to State SelfEsteem. Structural Equation Modeling. $1(1): 35-47$.

Barnes, Stuart J., Mattsson, Jan., dan Sorensen, Flemming. 2014. Destination Brand Experience and
Visitor Behavior: A Testing Scale in the Tourism Context. Journals of Tourism Research. 48 (14):121-139.

Baron, Reuben $\mathrm{M}$ dan Kenny, David A. 1986. The Moderator-Mediator Variable Distinction in Social Psychological Research: Conceptual, Strategic, and Statistical Considerations. Journal of Personality and Social Psychology. 51(6):11731182.

Berry, Leonard L., Carbone, Lewis. P., dan Haeckel, Stephan. H. 2002. Managing the total customer experience. MIT Sloan Management Review. 43 (3): 8589.

Bodet, Guillaume. 2008. Customer Satisfaction and Loyalty in Service: Two Concepts, Four Constructs, Several Relationships. Journal of Retailing and Consumer Services Vol. 15, p. 156-162.

Bolton, Ruth N 1998. A dynamic Model of the Duration of the Customer's relationship with a Continuous Service Providers: The Role of Satisfaction. Marketing Science 17 (1): 45-65.

dan Drew, James H. 1991. A Multistage Model of Customers' Assessments of Services Quality and Value. Journal of Consumer Research 17 (3): 375-384.

Bowen, Jhon dan Shoemaker, Stowe. 1998. The antecedents and consequences of customer loyalty. Cornell Hotel Restaurant and Administration Quarterly 12( 25).

Brakus, J. Josko., Schmitt, Bernd Hofheim., dan Zarantonello,Lia. 2009. Brand Experience: What Is It? How Is It Measured? Does It Affect Loyalty?. Journal Of Marketing ,p.52-68. 
Chandrashekaran, Murali., Rotte, Kristin., Tax, Stephen S., dan Grewal, Rajdeep. 2007. Satisfaction Strength and Customer Loyalty. Journal of Marketing Research 44 (2) 153-163.

Chaudhuri, Arjun dan Holbrook, B.Morris. 2001. The Chain of Effects From Brand Trust and Brand Affects to Brand Performance: The Role of Brand Loyalty. Journal of Marketing Vol.65, p.81-93

Chinomona, Richard. 2013. The Influence of Brand Experience on Brand Satisfaction, Trust, and Attachment in South Africa. International Business and Economics Research Journal 12(10) 1303-1316.

Chiou, Jyh-Sen dan Droge, August. 2006. Service quality, trust, specific asset investment, and expertise: Direct and indirect effects in a satisfaction-loyalty framework. Journal of the Academy of Marketing Science. 34(4),p. 613-627.

Choi, Young Gin., Ok, Chihyung., dan Hyun, Seunghyup. 2011. Evaluating Relationships among Brand Experience, Brand Personality, Brand Prestige, Brand Relationship Quality, and Brand Loyalty: An Empirical Study of Coffeehouse Brands. University of Massachussets Amherst Libraries. Kansas.

Cleff, Thomas., Dorr, Silvia., Vicknair, Andrew., dan Walter, Nadine. 2013. Brand Experience How it Relates to Brand Personality, Consumer Satisfaction and Consumer Loyalty. An Empirical Analysis of the Adidas Brand. Interdisciplinary Management Research. Vol.9, p. 731-754.

Consume Media (consumer business media). 2013. Indonesia Pasar Potensial bagi Industri Kosmetik, http://indonesianconsume.com/.Juli 2015.
Cowley, Elizabeth. 2007. How Enjoyable Was It? Remembering an Affective Reaction to a Previous Consumption Experience. Journal of consumer research. 34 (12): 494-505.

Delgado-Ballester,

Elena.

2004. Applicability of a Brand Trust Scale Across Product Categories: A Multigroup Invariance Analysis. European Journal of Marketing. 38 (56):573-592.

Delgado-Ballester, Elena., Munuera-Aleman, Jose Luis., dan Yague-Guillen, Maria Jesus. 2003. Development and Validation of a Brand Trust Scale. International Journal of Market Research. 45 (1): 35-53.

Dinas Kependudukan dan Pencatatan SIpil Kota Surabaya. 2015. Jumlah Penduduk Surabaya Tahun 2015, http://dispendukcapil.surabaya.go.id/. Februari 2016.

Engel, James.F., Blackwell, Roger.D., dan Miniard, Paul.W. 1990. Consumer Behaviour (6th ed.). The Dryden Press. Chicago.

Ercis, Aysel., Unal, Sevtap., Candan, Burcu., dan Yildirim,Hatice. 2012. The Effect of Brand Satisfaction, Trust and Brand Commitment on Loyalty and Repurchase Intentions. Social and Behavioral Sciences Vol.58, p.13951404.

Ferdinand, Augusty Tae. 2002. Structural Equation Modelling dalam Penelitian Manajemen. FE UNDIP. Semarang

Fishbein, Martin dan Icek, Ajzen. 1975. Belief, Attitude, Intention, and Behavior: An Introduction to Theory and Research. Reading, MA: AddisonWesley.

Ghozali, Imam. 2005. Model Persamaan Struktural Konsep dan Aplikasi dengan 
Program AMOS Ver. 16.0. Badan Penerbit UNDIP. Semarang

Global Business Guide Indonesia. 2014. Indonesia's Cosmetics Market, http:/www.gbgindonesia.com/. Maret 2016.

Gounaris, Strathclyde dan Stathakopoulos, Vlassis. 2004. Antecedents and consequences of brand loyalty: An empirical study. Brand Management 11 (4): 283-306.

Ha, Hong Youl dan Perks, Helen. 2005. Effects of consumer perceptions of brand experience on the web: Brand familiarity, satisfaction and brand trust. Journal of Consumer Behaviour. 4 (6): 438-452.

Hair, Joseph.F., Hult, Tomas.M., Ringle, Christian., dan Sarstedt, Marko. 2014.

A Primer on Partial Least Squares Structural Equation Model (PLS-SEM. SAGE Publications, USA.

Harian Ekonomi Neraca. 2014. Industri Kosmetik Diprediksi Tumbuh 15\%, http:/www.kemenperin.go.id/. Juli 2015 .

Hiscock, Russell. 2001. Most trusted brands. Marketing 3(1):32-33.

Hussein, Ananda Sabil. 2015. Penelitian Bisnis dan Manajemen Menggunakan Partial Least Square (PLS) dengan SmartPLS 3.0. Modul Ajar Universitas Brawijaya.

, Ismail, Taufiq., dan Hapsari, Raditha. 2015. The Formation of Brand Loyalty ini Indonesian Restaurant Industry. European Journal of Tourism, Hospitality and Recreation. Vol. 6(2):67-98.

Indonesia Finance Today. 2014. Indonesia Lahan Subur Industri Kosmetik, http:/www.kemenperin.go.id/. Juli 2015.

Info Surabaya. 2011. 33 Mall dan Pusat Perbelanjaan di Kota Surabaya, http://www.infosby.asia/. Juli 2015.

Intana, Lila. 2013. Tren Konsumen The Body Shop di Indonesia Bergeser, http://SWA.co.id/. Agustus 2016.

Irawan, Handi. 2012. Karakter dan Perilaku Khas Konsumen Indonesia, http://marketing.co.id/. Agustus2016.

Jones, Michael A., dan Suh, Jaebeom. 2000. Transaction-specific satisfaction and overall satisfaction: An empirical analysis. Journal of Services Marketing 14 (2): I47-159.

Jonker, Catholijn M dan Treur, Jan. 1999. Formal Analysis of Models for the Dynamics of Trust based on Experiences. Lecture Notes in Computer Science. 1647: 221-231.

Kanalsatu. 2013. Pasar Kosmetik dalam negeri Masih Menjanjikan, http://kanalsatu.com/. Februari 2016.

Keller, Kevin Lane. 2003. Strategic Brand Management: Building, Measuring, and Managing Brand Equity. Pearson Prentice-Hall. Upper Saddle River, NJ.

Kementerian Perindustrian Republik Indonesia. 2014. Pasar Kecantikan Kebanjiran Kosmetik Impor, http:/ www.kemenperin.go.id/. Juli 2015.

Kompas Media. 2012. Pilihan Produk Kecantikan Bergantung Usia. http://female.kompas.com/. Juli 2015.

Kotler, Philip dan Keller, Kevin Lane. 2012. Marketing Management $14^{\text {th }}$ Edition. Pearson Education, New Jersey.

Koufaris, Marios dan Hampton-Sosa, William. 2002. Customer trust online: Examining the role of the experience 
with the website. CIS Working Paper Series. Zicklin School of Business, Baruch College, New York, NY.

Kuenzel, Sven dan Halliday, Sue Vaux. 2008. Investing antecedents and consequences of brand identification. Journal of Product and Brand Management. 17(5),p. 293-304.

Liputan 6. 2014. Tiga Sektor Ini Jadi Penunjang Utama Perekonomian Surabaya, http://bisnis.liputan6.com/. Februari 2016.

L'oreal. 2012. L'oreal Inaugurates it's Largest Factory in the World to Meet Fast Rising Demand in the South East Asian Beauty

Market, http://www.loreal.com/. Januari 2016.

Lovelock ,Christopher dan Wirtz, Jochen. 2012. Services Marketing Management. Pearson, New Jersey.

Luk, Sherriff T.K., dan Yip, Leslie.S.C. 2008. The moderator effect of monetary sales promotion on the relationship between brand trust and purchase behavior. Brand Management. 15 (6): 452-464.

McDaniel, Carl dan Gates, Roger. 2010. Marketing Research, $8^{\text {th }}$ Edition. John Wiley \& Sons, New York.

Metekohy, Stellamaris. 2011. Pengaruh Strategi Resource-Based dan Orientasi Kewirausahaan terhadap Keunggulan Bersaing Usaha Kecil dan Usaha Mikro (Studi pada Usaha Jasa Etnis Maluku). Jurnal Aplikasi Manajemen Vol. 11:12-20.

Mittal, Vikas dan Kamakura, Wagner. 2001. Satisfaction, Repurchase Intent, and Repurchase Behavior: Investigating the Moderating Effect of Customer Characteristics. Journal of Marketing Research 38 (2001)131-142.
Moleong, Lexy J. 2002. Metodologi Penelitian Kualitatif. PT. Remaja Rosdakarya, Bandung.

Morrison, Sharon dan Crane, G. Frederick. 2007. Building the Service Brand by Creating and Managing an Emotional Brand Experience. Journal of Brand Management 14: 410-421.

Murphy, Sheila $\mathrm{T}$ dan Zajonc, Robert B. 1993. Affect, Cognition and Awareness: Affective Priming with Optimal and Suboptimal Stimulus Exposures. Journal of Personality and Social Psychology 64 (5): 723-39.

Ningsih, Sri Minarti. dan Segoro, Waseso. 2014. The Influence of Customer Satisfaction, Switching Cost and Trust in a Brand on Customer Loyalty-the Survey on Student as im3 Users in Depok, Indonesia. Journal of Social and Behavioral Sciences. 143(14):1015-1019.

Oliver, Richard L dan Rust, Roland T. 1997. Customer Delight: Foundations, Findings, and Managerial Insight. Journal of Retailing. Vol. 73. no. 3 p.311-336.

Park, C Wan dan Macinnis, Deborah J. 2006. What's In and What's Out: Questions over the Boundaries of the Attitude Construct. Journal of Consumer Research 33 (1) :16-18.

Patterson, Paul G., Johnson, Lester W., dan Spreng, Richard A. 1997. Modelling the determinants of customer satisfaction for business-to-business professional services. Journal of the Academy of Marketing Science 25 (1): 4-17.

Ponsonby-McCabe, Sharon dan Boyle, Emily. 2006. Understanding brands as experiential spaces: Axiological implications for marketing strategists. 
Journal of Strategic Marketing 14 (2): 175-189.

Prasetyo, Bambang dan Jannah, Lina Miftahul. 2005. Metode Penelitian Kuantitatif : Teori dan Aplikasi. PT. Raya Grafindo Persada,Jakarta.

Preacher, Kristopher J. 2010. Calculation for the Sobe lTest. http://quantpsy.org/sobel/sobel.htm. Juni 2016.

Reichheld, Frederic F. 1996. The Loyalty Effect: The Hidden Force Behind Growth, Profits And Lasting Value. Boston, Harvard Business School Press.

Russell-Bennett, Rebekah., Hartel, Charmine E.J., dan Mccoll-Kennedy,Janet R. 2005. Experience as a Moderator of Involvement and Satisfaction on Brand Loyalty in a Business-to-Business Settings. Industrial Marketing Management. 34: 97-107.

dan Rundle-

Thiele,Sharyn. 2002. A Comparison of Attitudinal Loyalty Measurement Approaches. Brand Management. Vol 9, no.3, p.193-209.

Sahin, Azize., Zehir, Cemal., dan Kintapci, Hakan. 2011. The Effects of Brand Experiences, Trust and Satisfaction on Building Brand Loyalty; An Empirical Research On Global Brands. Procedia Social and Behavioral Sciences 24 p.1288-1301.

Santoso, Singgih. 2012. Structural equation modeling: Konsep dan Aplikasi dengan AMOS. PT. Elex Media Komputindo, Jakarta.

Sanusi, Ahmad. 2011. Metodologi Penelitian Bisnis. Salemba Empat, Jakarta.
Schmitt, Bernd Hofheim. 1999. Experiental Marketing. Journal of Marketing Management (15):53-67.

dan Rogers, David

L. 2008. Handbook on Brand and Experience Management. Cheltenham. UK and Northampton, MA: Edward Elgar.

Seiders, Kathleen., Voss, Glenn B., Grewal, Dhruv., dan Godfrey, Andrea L. 2005. Do Satisfied Customers Buy More? Examining Moderating Influences in a Retailing Context. Journal of Marketing 69(10): 26-43.

Sekaran, Uma. 2003. Research Methods for Business $4^{\text {th }}$ Edition. John Wiley \& Sons, USA.

Simon, Herbert A. 1993. Decision-making: Rational, non rational and irrational. Educational Administration Quarterly 29 (3): 392- 411.

Singarimbun,Masri dan Effendi, Sofyan. 2006. Metode Penelitian Survai. LP3ES, Jakarta.

Solimun. 2010. Memahami Metode Kuantitatif Mutakhir Structural Equation Modeling dan Partial Least Square. Malang. Program Studi Statistika FMIPA Universitas Brawijaya, Malang.

Spire. 2013. Indonesian Market Focus Skin Care \&Cosmetics. http://www.spire.com/, Juli 2015.

Statista (The Statistics Portal). Breakdown of the Cosmetic Market Worldwide from 2011 to 2014 by Product Category. http://www.statista.com/.November 2015.

Sugiyono. 2006. Satistika untuk Penelitian. Alfabeta, Bandung. 
Sukmadinata, Nana Syaodih 2008, Metode Penelitian Pendidikan. Remaja Risdakarya, Bandung.

Rundle-Thiele, Sharyn dan Mackay, Maio. 2001. A brand for all seasons? A discussion of brand loyalty approaches and their applicability for different markets. Journal of Product and Brand Management 10 (1): 25-37.

Thomson, Matthew., MacInnis, Deborah J., dan Park, C Whan. 2005. The Ties That Bind: Measuring the Strength of Consumers Emotional Attachments to Brands. Journal of Consumer Psychology. 15 (1): 77-91.

Ueacharoenkit, Supawan. 2012. Experiental Marketing-A Consumption of Fantasies, Feelings and Fun (An Investigation of the Relationship Between Brand Experience and Loyalty Within the Context of the Luxury Cosmetics Sector in Thailand). Tesis Universitas Brunel London.

Universitas Pendidikan Indonesia. 2011. Experiential Marketing and Brand Experiences:Experiential Marketing a Practical Guide to Interactive Brand Experiencess. UNPI, Indonesia.

Urban, Glen L., Sultan, Fareena., dan Qualls, William J. 2000. Placing trust at the center of your internet strategy. Sloan Management Review. 41 (Fall): 39-48.

Website Tunjungan Plaza. 2010. Tenant Tunjungan Plaza Surabaya. http://www.tunjunganplaza.com/. Juli 2015.

Weinberg, Bruce D. 2001. Research in exploring the online consumer experience. Advances in Consumer Research. 28 (1): 227-232.

Westbrook, Robert A dan Reilly, Michael D. 1983. Value-precept disparity: An alternative to the disconfirmation of expectations theory of consumer satisfaction. Advances in Consumer Research. 10 (1): 256-261.

Wijayanto, Setyo Hari. 2008. Konsep dan Tutorial Structural Equation Modelling dengan LISREL 8.8. Graha Ilmu, Yogyakarta.

Yoon, Sung Joon. 2002. The antecedents and consequences of trust in onlinepurchase decisions. Journal of Interactive Marketing. 16 (2): 47-63.

Zarantenello, Lia dan Schmitt, Bernd Hofheim. 2000. Using the Brand Experience Scale to Profile Consumers and Predict Consumer Behavior. Brand Management 17(7):532-540. 